\title{
Antithrombotic, procoagulant, and fibrinolytic mechanisms in cerebral circulation: implications for brain injury and protection
}

\author{
Berislav V. Zlokovic, M.D., Ph.D.
}

Department of Neurosurgery and Division of Neurosurgery, Childrens Hospital, University of Southern California School of Medicine, Los Angeles, California

Maintaining a delicate balance among anticoagulant, procoagulant, and fibrinolytic pathways in the cerebral microcirculation is of major importance for normal cerebral blood flow. Under physiological conditions and in the absence of provocative stimuli, the anticoagulant and fibrinolytic pathways prevail over procoagulant mechanisms. Blood clotting is essential to minimize bleeding and to achieve hemostasis; however, excessive clotting contributes to thrombosis and may predispose the brain to infarction and ischemic stroke. Conversely, excessive bleeding due to enhanced anticoagulatory and fibrinolytic mechanisms could predispose the brain to hemorrhagic stroke. Recent studies in the author's laboratory indicate that brain capillary endothelium in vivo produces thrombomodulin (TM), a key cofactor in the TM-protein $\mathrm{C}$ system that is of major biological significance to the antithrombotic properties of the blood-brain barrier (BBB). The BBB endothelium also expresses tissue plasminogen activator (tPA), a key protein in fibrinolysis, and its rapid inhibitor, plasminogen activator inhibitor (PAI-1). The procoagulant tissue factor is normally dormant at the BBB. There is a vast body of clinical evidence to document the importance of hemostasis in the pathophysiology of brain injury. In particular, functional changes caused by major stroke risk factors in the TM-protein C, tPA/PAI-1, and tissue factor systems at the BBB may result in large and debilitating infarctions following an ischemic insult. Thus, correcting this hemostatic imbalance could ameliorate drastic CBF reductions at the time of ischemic insult, ultimately resulting in brain protection. Delineation of the molecular mechanisms of BBB-mediated hemostasis will likely contribute to future stroke prevention efforts and brain protection strategies.

Key Words * cerebral circulation * ischemia * blood-brain barrier * hemostasis * brain injury * neuroprotection

The activities and interactions among clot-preventing (anticoagulant), clot-forming (procoagulant), and clot-dissolving (fibrinolytic) pathways in the brain are closely controlled under physiological conditions. Normally, the anticoagulant and fibrinolytic pathways prevail over procoagulant pathways, which is critical for normal brain functioning and maintenance of cerebral blood flow (CBF). In recent years, a new concept has emerged that suggests that alterations in hemostatic equilibrium may predispose the brain to cerebrovascular disease and stroke. Normal blood clotting is essential to minimize bleeding and to achieve hemostasis; however, excessive clotting contributes to thrombosis and may have severe consequences in the central nervous system (CNS), which include brain infarction and ischemic stroke. 
Conversely, excessive bleeding due to enhanced anticoagulatory mechanisms could predispose the brain to hemorrhagic stroke. Thus, controlling the balance among different hemostatic functions in the cerebral microcirculation could play a major role in brain protection.

Several clinical studies have indicated that patients with acute brain infarction have disturbances in the anticoagulant mechanism,[80,101] as well as impaired fibrinolysis.[100] It has been suggested that these hemostatic abnormalities could be regarded as risk factors for brain infarction. Although it has not been established whether they play a causal role in the pathogenesis of stroke, it is likely that correcting hemostatic abnormalities may protect the brain either by reducing the risk of stroke and/or by ameliorating brain injury following a focal ischemic insult.

Recent studies in our laboratory have focused on the link between "local" cerebrovascular hemostatic mechanisms in vivo and brain injury following focal ischemic insult.[70,118-120,132,133] The expression and function of hemostasis-related proteins in brain microvessels, that is, the site of the blood-brain barrier (BBB), were studied during exposure to major stroke risk factors. These studies have indicated that cerebrovascular capillary endothelium in vivo produces functionally active anticoagulant protein and thrombomodulin (TM), $[118,120]$ as well as tissue plasminogen activator (tPA), and plasminogen activator inhibitor (PAI-1),[70,119,132,133] the two key proteins involved in fibrinolysis within the vascular system. A schematic representation of hemostatic functions of the BBB in the basal state and in the absence of provocative stimuli is shown in Fig. 1 and will be discussed in detail later. We have also demonstrated that rats subjected to stroke risk factors may be a suitable model in which changes in the expression and activity of cerebromicrovascular TM-protein $\mathrm{C}$ anticoagulant system and tPA/PAI-1 fibrinolytic system can be studied in vivo in relation to ischemic stroke and brain injury.[70,119,120] 


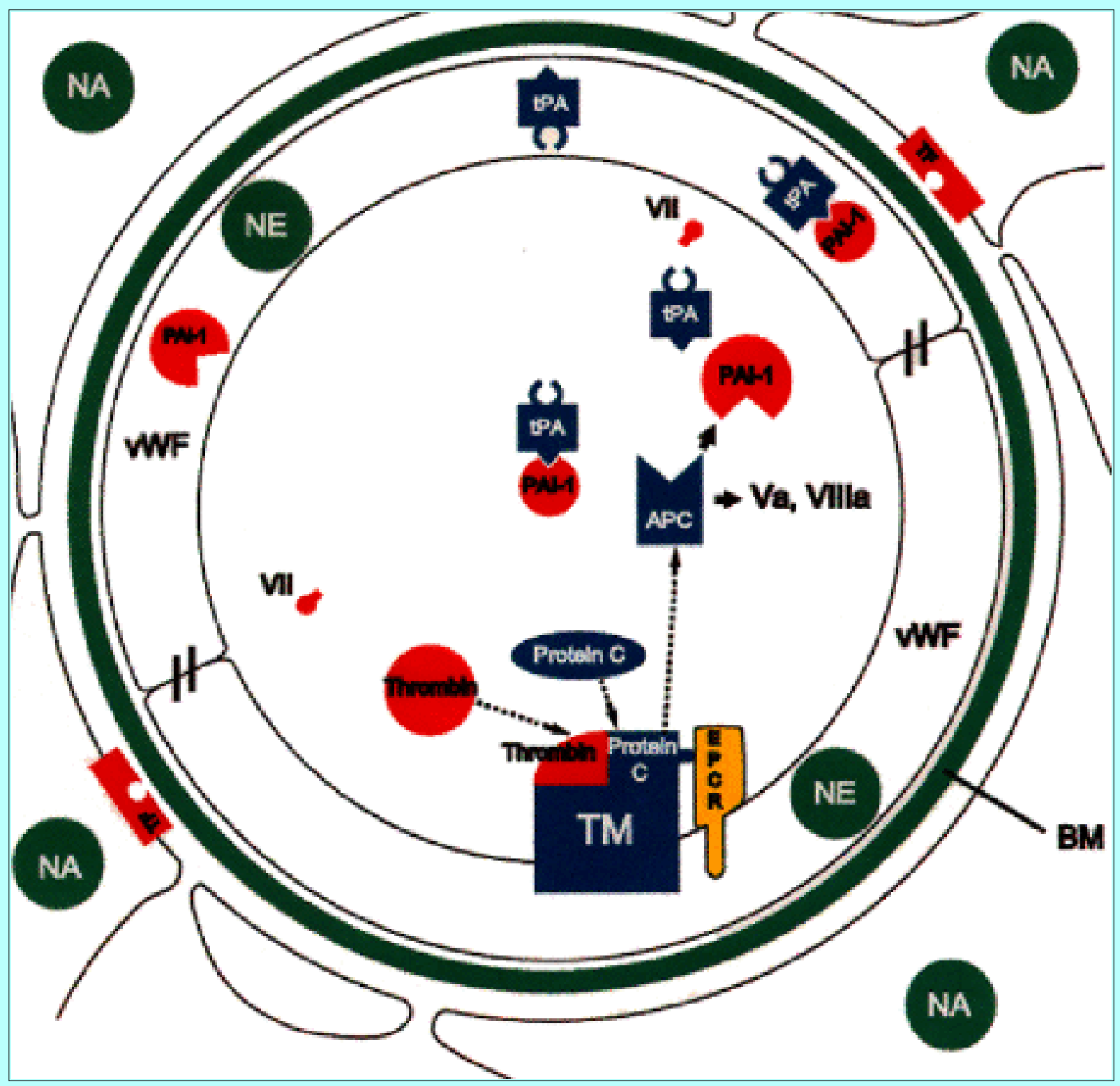

Fig. 1. Schematic drawing illustrating hemostatic mechanisms involved in cerebral microcirculation in the basal state (see text for detailed information).

\section{Antithrombotic Mechanisms}

Antithrombotic mechanisms in the cerebral microcirculation are governed by several factors that depend on the hemostatic properties of cerebromicrovascular endothelium; however, these factors may also be modified by hemostatic abnormalities in systemic circulating blood. The antithrombotic properties of cerebrovascular endothelium at the level of the BBB include: 1) the presence of TM, an integral membrane anticoagulant protein, expressed at the luminal side of brain endothelial cells; 2) the absence of procoagulant tissue factor (TF) in brain endothelium and the barrier that prevents circulating coagulation factors to cross into brain parenchyma and initiate the extrinsic clotting mechanism upon interaction with TF on astrocytes; 3) the physicochemical properties of the luminal endothelial membrane that prevent the attachment of platelets and the contact phase amplification of the intrinsic clotting mechanism.[132]

Other endothelium-derived mechanisms may include production of prostacyclin, a potent inhibitor of platelet aggregation and adherence or complexing of antithrombin III to cerebrovascular heparan sulfate. These mechanisms, however, may be less significant at the intact BBB because endothelial cells isolated 
from cerebral microvessels secrete barely detectable amounts of prostacyclin, in contrast to cells isolated from large cerebral vessels.[30] Heparan sulfate from cerebral microvessels exhibits a small amount of anticoagulant activity in vitro, but is located in situ exclusively on the abluminal side of brain capillaries.[117]

\section{The TM-Protein C System}

Thrombomodulin is an endothelial cell transmembrane glycoprotein and a key cofactor in the TM-protein C/protein S pathway, which is of major biological significance for the antithrombotic properties of endothelial cells. Thrombomodulin is a high-affinity receptor for thrombin on endothelial cell luminal surfaces, $[28,34,35]$ and the thrombin-TM complex is a potent activator of circulating protein $\mathrm{C}$ (Figs. 1 and 3). It has been shown recently that endothelial cell protein $\mathrm{C}$ receptor (EPC-R) augments protein $\mathrm{C}$ activation via the thrombin-TM complex.[110] It has been suggested that EPC-R presents protein $\mathrm{C}$ to the thrombin-TM complex for activation. The activated protein $\mathrm{C}$ (APC) is an antithrombotic enzyme (that is, a serine protease) that inactivates the coagulation factors Va and VIIIa by proteolytical degradation. [28,34,35] This function of APC is accelerated by protein S, another cofactor. The APC also promotes fibrinolysis by inhibiting PAI-1.[16] The importance of the TM-protein C system in offering major protection against a variety of thrombotic events has been well documented.[49] Natural protein $\mathrm{C}$ knockout experiments show us a great deal about the physiological importance of APC. Newborn infants who are totally deficient in anticoagulant protein $\mathrm{C}$ suffer from extensive thrombosis with inflammation in the microvasculature. This condition is lethal unless it is treated aggressively, and most infants suffer irreversible loss of vision and brain damage. The endogenous APC circulates at a 40 pmol concentration in human blood and has a remarkably long half-life of 0.3 hours,[60] suggesting that it is part of a systemic anticoagulant and antiinflammatory surveillance system.

It has been shown that anti-TM antibodies potentiate thrombin-induced thromboembolism in mice,[72] whereas purified or recombinant TM protects against thromboembolism in this model.[48,72] Infusions of APC provide protection against procoagulant and lethal effects in a sepsis model.[112] Resistance to the effects of APC (due to the mutation in factor V gene and homocysteinemia) is closely linked to venous thrombosis in humans[111] and could also be a potential hemostatic risk factor for stroke and heart attack. Recent studies in stroke populations have examined protein $\mathrm{C}$ antigen and protein $\mathrm{C}$ zymogen activity after in vitro addition of snake venom, or other exogenous activators, $[3,18,23,80]$ as well as the activity of the circulating antithrombotic enzyme, APC.[51] It has been reported that low plasma protein $\mathrm{C}$ levels were related to poor outcome after stroke and may have been caused by protein $\mathrm{C}$ depletion because of excessive thrombin generation and rapid APC clearance.[23] It has also been shown that stroke patients have lower levels of circulating APC compared with control patients and community control subjects.[79] Because protein C antigen and APC levels were not measured before the stroke in these studies, it is difficult to say whether observed reductions preceded or followed the neurological event.

Low circulating APC may result from the depletion of the protein $\mathrm{C}$ zymogen precursor, increased levels of circulating APC inhibitors, or reduced protein C generating capacity, due to low levels of intravascular thrombin or reduced TM and/or EPC-R on endothelial surfaces.[49] Although the role of APC as a normal and potent component of the blood's host defense mechanisms has been well defined, relatively little is known about the capability of brain cerebrovascular endothelium to activate protein $\mathrm{C}$ in vivo. It has been recently reported that TM is expressed in cultured bovine brain endothelial cells.[113] 
Immunocytochemical studies in human brain have yielded conflicting results. Some studies claimed an absence or a very limited expression of TM protein in capillaries from normal human brain.[65,66,81] Other studies reported that TM protein was present in human brain microvessels[13,126] and suggested that TM was substantially reduced in subcortical regions where infarction is common.[126]

Recently, we demonstrated that TM messenger (m)RNA and TM activity (determined by a protein C activation assay) are present in both bovine and rat brain capillaries, but absent in brain parenchyma (Fig. 2). $[118,120]$ Thrombomodulin has been cloned in a number of species including human, bovine, and mouse. $[27,67,122]$ Recently, we reported that the sequence and structure of a functional portion of the TM gene isolated from cortical brain capillaries in rats is comparable to other species.[120] The coding sequence of the rat brain capillary TM complementary DNA (approximately $1500 \mathrm{bp}$ ) indicated 75 to $90 \%$ homology with the mouse, bovine, and human sequences.[118,120] The predicted amino acid sequence demonstrated the presence of characteristic epidermal growth factor (EGF)-like tandem repeats responsible for binding and internalization of thrombin, a serine/threonine rich region and a membrane-spanning domain. Based on these findings it has been suggested that CNS microvascular endothelium is capable of producing TM in a similar way to that of systemic vascular endothelial cells. [28,34,35]

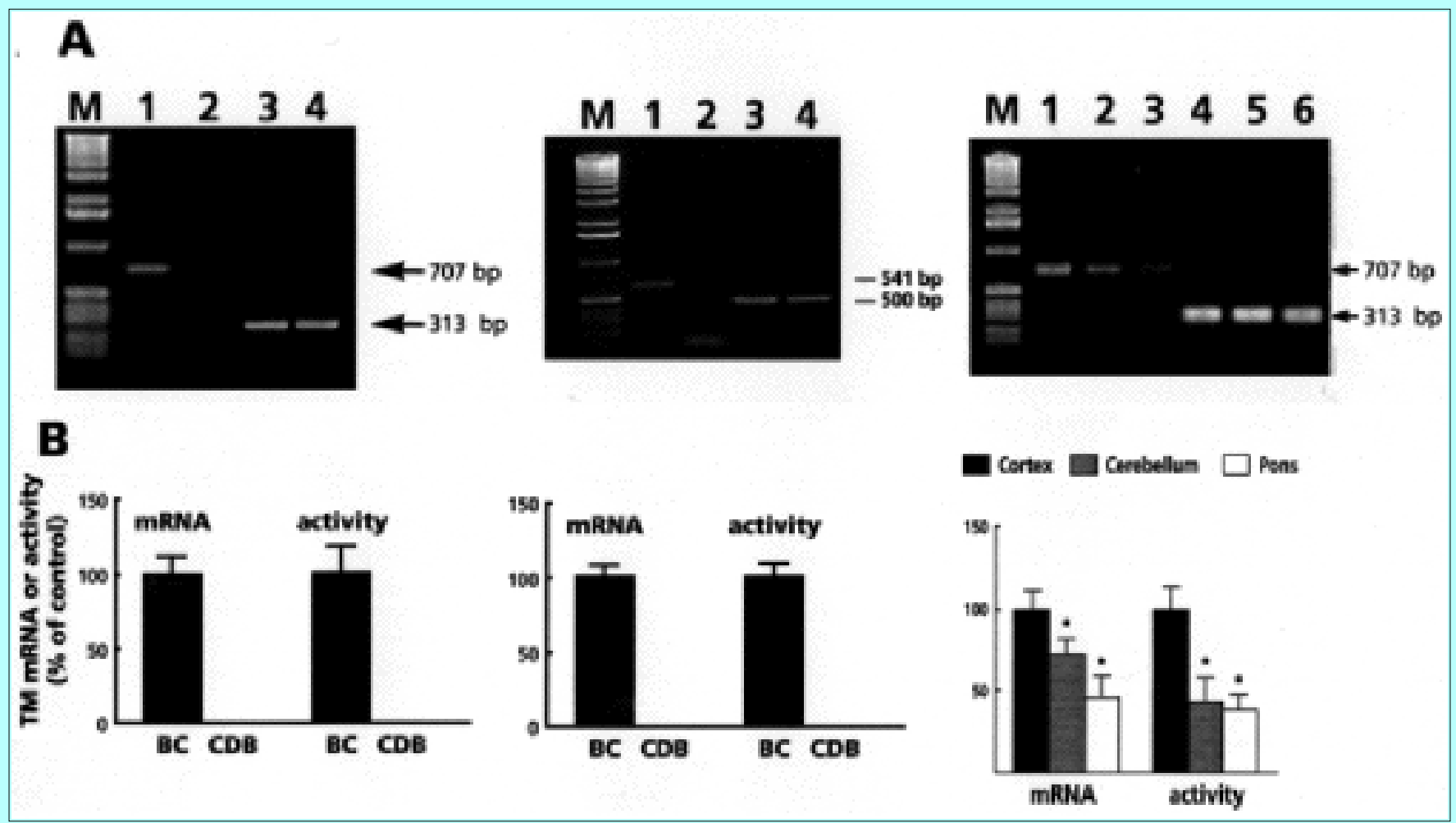

Fig. 2. A: Western blot analyses of the presence of TM mRNA transcript in cortical brain capillaries (BC), and its absence in capillary-depleted brain (CDB) in cow (left) and rat (middle). Regional levels of TM mRNA transcript in the BC of bovine cortex, cerebellum, and pons (right). Agarose gel (1\%) stained with ethidium bromide shows the results of polymerase chain reaction amplifications using TM-specific bovine and rat primers. As an internal control for unchanging gene expression, the amplification, using $\beta$-actin primers, is shown. $\mathrm{M}$ is the DNA marker. Bands: bovine TM, $707 \mathrm{bp}$; bovine $\beta$-actin, $313 \mathrm{bp}$; rat TM, $541 \mathrm{bp}$; rat $B$-actin, 500. B. Graphs depticting the relative abundance of TM versus $B$-actin mRNA as determined by scanning densitometry and TM activity from BC (solid bars) and CDB (absence of transcript and activity) (left and middle). Relative regional levels of TM 
mRNA and activity (right). Endothelial cell TM activity was assayed from capillary cellular homogenates by measuring the increase in APC. The values are expressed as mean \pm standard deviation of five experiments. Values in cortical BC are arbitrarily set as 1 ; *p lt 0.05 versus cortical BC. Graphs are modified from data derived from references $118,120,121$.

The concept that TM at the BBB is an important physiological anticoagulant within the brain microcirculatory system raises the question of whether impairments in the brain's endothelial TM-protein C system could predispose to the development of vascular thrombosis, ischemic stroke, and brain injury, as in a case of venous thrombosis and coronary occlusion.[109,111] We have demonstrated that cerebrovascular TM mRNA expression and TM activity in bovine brain may vary in a region-dependent manner (Fig. 2) in agreement with an earlier report on human brain.[126] At present it is not known whether lower levels of TM brain capillary expression may predispose the brain to an ischemic event and what factors are responsible for regional variations. However, it is likely that lower levels of brain capillary TM in certain brain regions could reflect reduced local anticoagulant brain capacity, which may favor a thrombotic event similar to those suggested for other organs.[109,111]

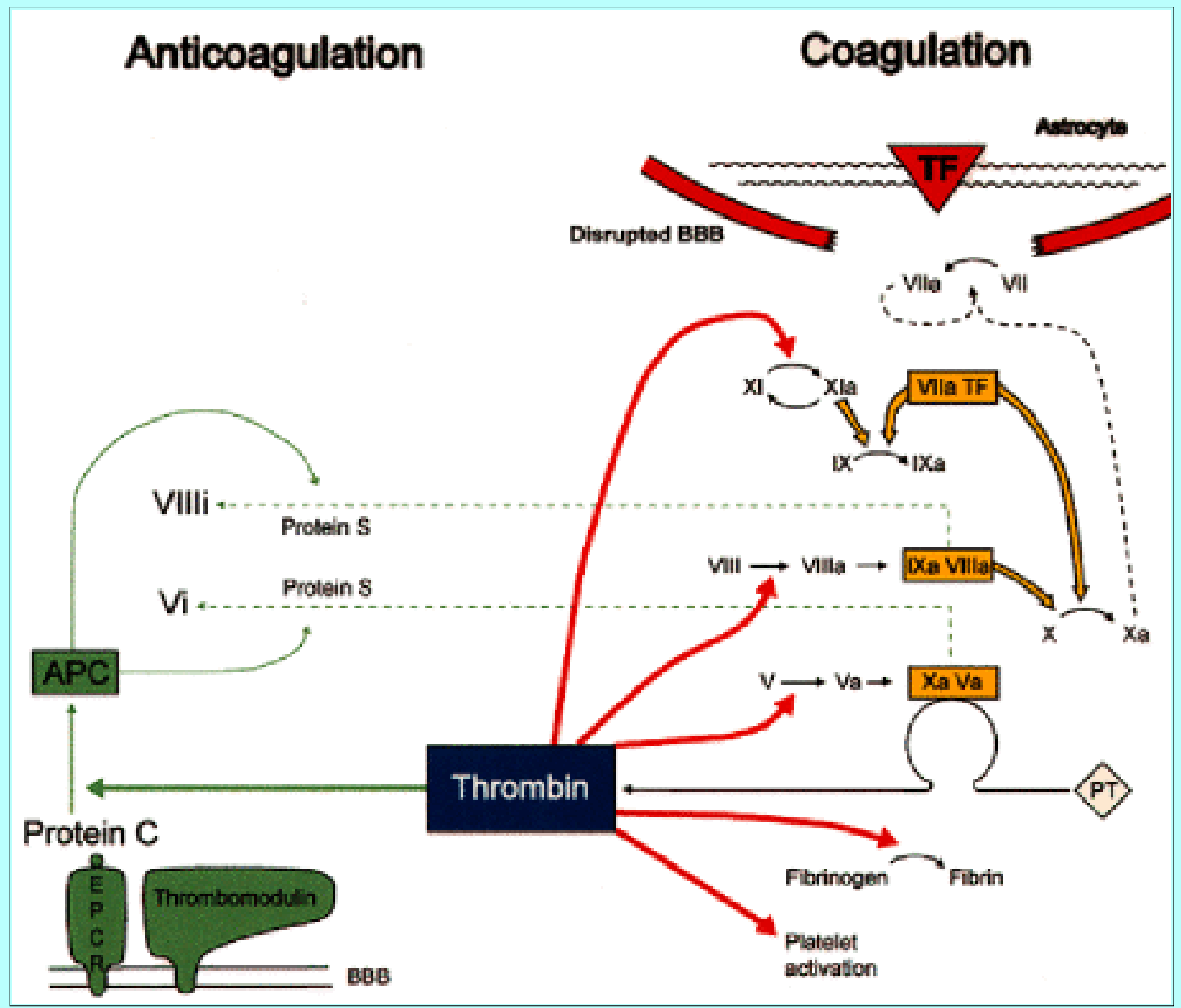

Fig. 3. This schematic illustrates the role of thrombin in blood coagulation and anticoagulation pathways in brain (see text for detailed explanation).

\section{The Thrombin Paradox}


As recently described by Griffin,[49] the thrombin paradox is like the so-called French red wine paradox;[99] too much thrombin or red wine is harmful to blood vessels, but a little bit of either is much better than none of all. As illustrated in Fig. 3, thrombin can both promote and prevent blood clotting. Low levels of thrombin[55] generate markedly increased levels of endogenous circulating APC.[52] On the other hand, high levels of thrombin cause blood to clot by generating procoagulant activation factors $\mathrm{Va}$ and VIIIa through the conversion of fibrinogen to fibrin and by activating platelets that express their cell-surface receptors and provide various prothrombotic agents. A "J" curve that describes the relationship between the thrombotic potential of blood and thrombin concentration is depicted in Fig. 4. Because the affinity of wild-type thrombin (Glu-229) for TM is very high and there is an abundance of TM in microcirculation, low levels of thrombin have an antithrombotic effect. Higher levels of free thrombin, however, exert various prothrombotic activities. It has been reported recently that the mutation of glutamic acid to alanine at position 229 of the protein sequence creates Ala 229 thrombin, which has dramatically different specificity, both in vitro and in vivo.[44] The result of this mutation is that thrombin procoagulant activities almost disappear, whereas its anticoagulant activity is conserved.

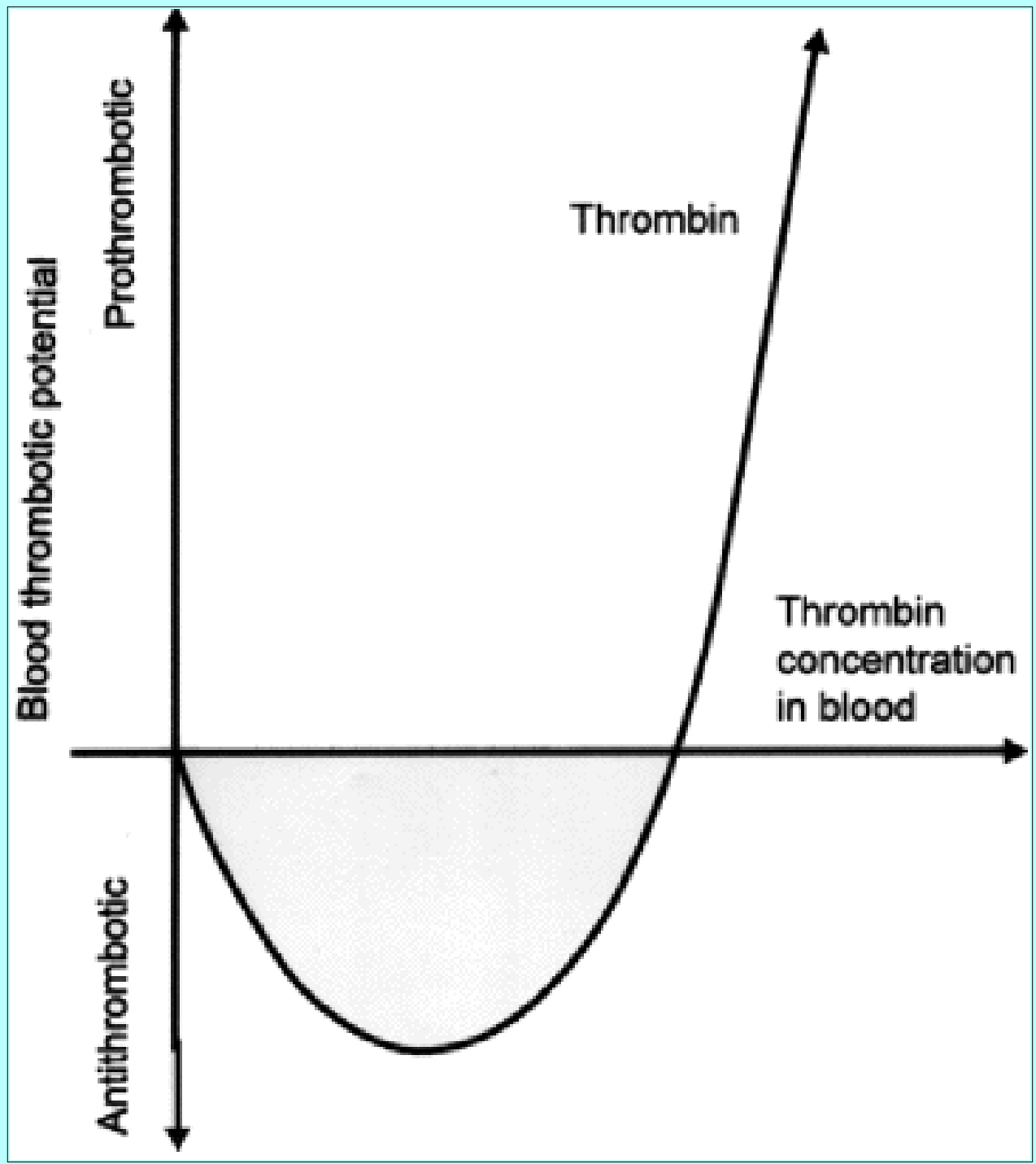

Fig. 4. A "J" curve illustrating the thrombotic potential of blood as a function of the relative concentration of wild-type circulating thrombin. Modified from reference 49.

\section{PROCOAGULANT MECHANISMS}

Despite major advances in our understanding of blood coagulation in vitro, relatively little is known 
about the functions of coagulation mechanisms in vivo,[43] and in particular within brain circulation.[132] The key to initiation of the coagulation protease cascade is TF (also known as tissue thromboplastin). Tissue factor is an integral membrane protein expressed on the surface of nonvascular cells and it is a member of the cytokine/hematopoietic growth factor receptor family.[10] Tissue factor is constitutively expressed by extravascular cells such as cells in the tunica adventitia surrounding major vessels, as well as cells delimiting organ boundaries.[29,40] Consistent with its role in hemostasis and the great sensitivity of brain to hemorrhage, high levels of TF mRNA and functional protein are found in the brain.[4,58,125] Earlier immunohistochemical studies analyzing human TF antigen expression observed a diffuse staining throughout the brain parenchyma and were not able to identify the cellular source of TF in brain.[29,40,82] More recent studies, however, have demonstrated that astrocytes constitutively express TF mRNA and TF functional protein.[31] These results suggest that astrocytes, in addition to their role in neuronal support and BBB formation, may be intimately involved in preventing hemorrhage within the CNS.

Although the TF gene exhibits a distinct pattern of tissue-specific expression in vivo, TF is also inducible in response to a variety of stimuli in several cell types that do not constitutively express TF. Tissue factor has been defined as an immediate-early gene in fibroblasts[58] and is induced by inflammatory mediators in systemic endothelial cells and cells of monocyte lineage.[32] Under normal conditions, TF is not expressed by the endothelium at the BBB as we reported.[39] When the cerebral endothelial membrane is damaged, as in the case of traumatic or ischemic insult, the barrier that prevents TF exposure to circulating blood is lost and the extrinsic coagulation process can be initiated. This response may be potentiated by the inflammatory component of the CNS injury. At present, however, it is not known whether brain endothelium can also become a site that expresses TF following CNS injury.

The current concept of blood coagulation suggests an interaction between extrinsic and intrinsic mechanisms (Fig. 3).[8] The extracellular domain of TF is the factor VII receptor. Normally, the BBB prevents factor VII, as well as other coagulation factors, from diffusing beyond the endothelial capillary wall. When plasma comes in contact with TF, factor VII binds to its receptor and the TF-activated-factor VIIa complex activates factors IX and X.[43] Factor IXa forms a complex with factor VIIIa and activates factor X; factor Xa forms a complex with factor Va and activates prothrombin.[43] Thrombin cleaves fibrinogen, yielding monomeric fibrin, which then polymerizes to form a fibrin clot. It has been suggested that components of the extrinsic pathway activate the intrinsic pathway, which is dormant in the generation of factor Xa or thrombin in vivo.[9] The exposure of the subendothelial basement membrane after BBB disruption may activate the contact phase that amplifies the intrinsic mechanism. $[9,43]$

In parallel with the coagulation process, cerebrovascular injury prompts circulating platelets to marginate against the vessel wall.[43] Their adherence is most likely mediated by von Willebrand factor (vWF) released from endothelial cells. von Willebrand factor binds to glycoprotein Ib on the platelet membrane and activated platelets degranulate and rapidly express factor VIII and V receptors and P-selectin (leukocyte receptor on platelets) on their surfaces. Platelets aggregate in an interaction mediated by fibrinogen and the fibrinogen receptor (glycoprotein IIb-IIIa complex on platelets) and form a platelet plug. Circulating leukocytes may also interact with the microvascular endothelium and platelets via different receptor adhesion molecules (selectins),[83] which further compromises brain circulation and $\mathrm{CBF}$. 
When a cerebral clot is formed, a large amount of plasminogen is trapped in the clot with other plasma proteins. Plasminogen requires activation to become plasmin.[42] Plasmin is a trypsinlike enzyme with fibrinolytic activity that digests fibrin, fibrinogen, and factors V, VIII, and XII. Fibrinolysis promotes slow clearing of clotted blood and eventually reopens cerebral microcirculation. The tPA and PAI-1 play key roles in the control of fibrinolysis within the vascular system.[21,78] Much of tPA in normal plasma and in tissues is inactive and exists as a part of a complex with PAI-1 that is considered to be a primary endogenous inhibitor of tPA in plasma and in tissues.[78] It has been suggested that tPA and PAI-1 expression may vary among species, tissues, and with the type of stimulation.[12,33,70,71,75,91,133] The expression of tPA and PAI-1 has recently been shown in bovine[71] and human[107] brain microvascular endothelial cells in vitro.

Recently, we reported that tPA and PAI-1 are normally expressed in vivo in cerebral capillaries in rodents and that both tPA and PAI-1 antigens and tPA and PAI-1 mRNAs are preserved in microvessels isolated immediately ex vivo in rodent brain. $[70,119,132,133]$ Immunocytochemical analysis of brain tissue in rats has confirmed the localization of both tPA and PAI-1 antigens in different sizes of microvessels including brain capillaries. Western blot analysis of cerebromicrovascular proteins has shown that in addition to a free pool of tPA, a significant amount of brain capillary tPA is present in its inactive form as tPA-PAI-1 complexes. The ratio between free tPA and tPA-PAI-1 complexes is 1:3.4 (Fig. 5A and C). We have also reported that there is a relatively large pool of free PAI-1 in brain microvessels. The ratio between free PAI-1 and tPA-PAI-1 complexes is 6.3:1 (Fig. 5B and D).[119] The factors responsible for the tPA-PAI-1 complex in brain microvasculature in vivo are currently unknown; however, the fact that there is a free tPA pool in brain capillaries led us to propose that brain endothelium may make an important contribution to fibrinolytic mechanisms in cerebral microcirculation. In addition to the vascular effects of tPA[133] there are other roles for tPA in mature brain, including mediation of activity-dependent synaptic plasticity, such as during motor learning[106] and long-term potentiation[98] and a role in some types of neuronal degeneration induced by excitotoxins.[114] 


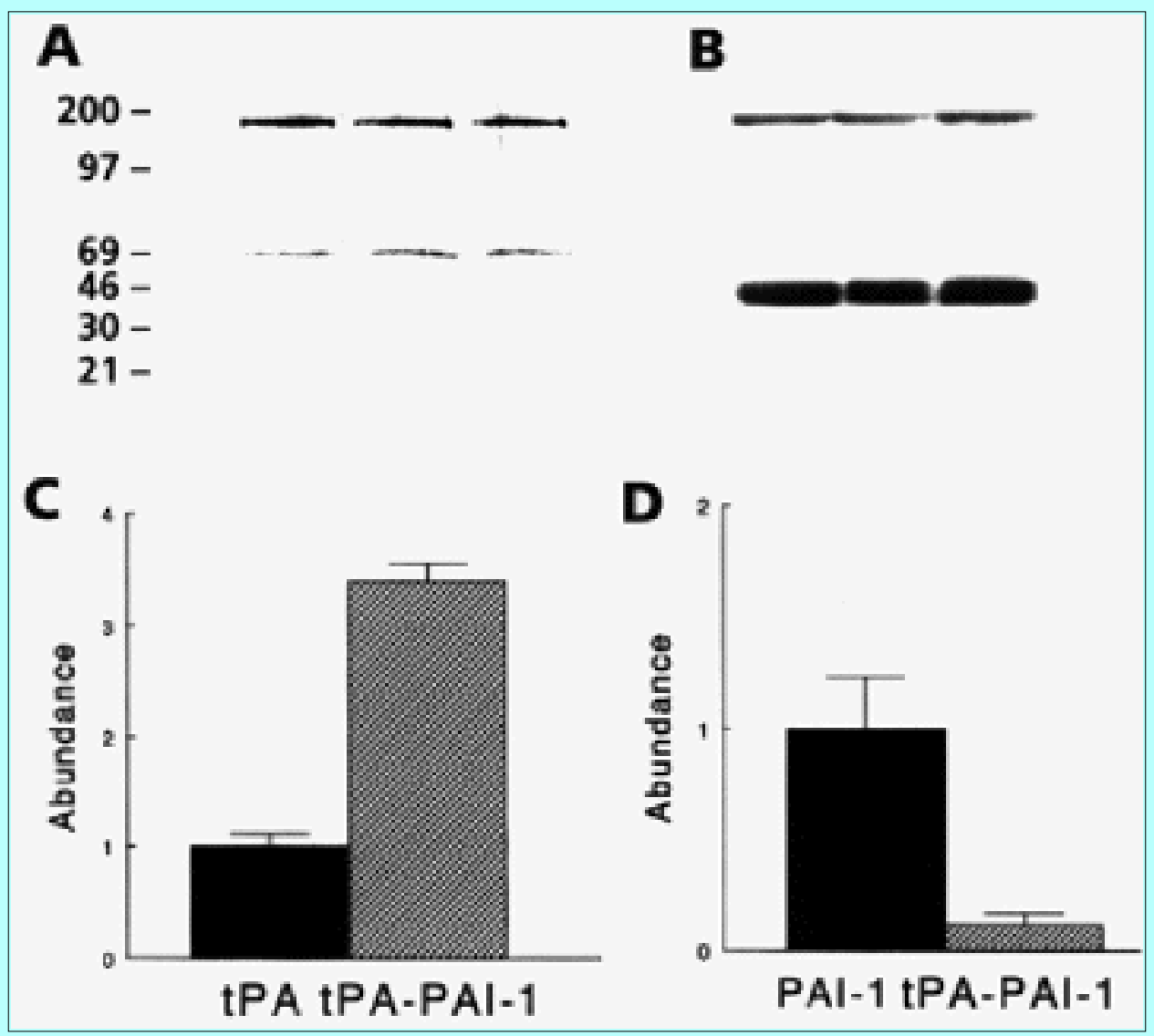

Fig. 5. Immunodetection of free tPA, PAI-1 and tPA-PAI-1 complexes in cerebral capillaries of normal rats. Brain capillary proteins were resolved by sodium dodecyl sulfate-polyacrylamide gel electrophoresis and probed with anti-tPA antibodies that recognize free tPA antigen and tPA-PAI-1 complexes (A) and anti-PAI-1 antibodies that recognize free PAI-1 antigen and tPA-PAI-1 complexes (B). Numerical values represent the mobility of molecular weight markers in kilodaltons. The bands illustrating molecular mobility $\left(M_{r}\right)$ of tPA antigen $\left(M_{r}=67,000\right)$, and the PAI-1 antigen $\left(M_{r}=45,000\right)$ are shown in $\mathrm{A}$ and $\mathrm{B}$, respectively; tPA-PAI-1 complexes $\left(\mathrm{M}_{\mathrm{r}}\right.$ approximately $\left.112,000 \mathrm{kD}\right)$ are shown both in A and B. Graphs depicting the relative abundance of tPA and PAI-1 antigens and tPA-PAI-1 complexes as determined by scanning densitometry of blots incubated with anti-tPA antibodies (C) and anti-PAI-1 antibodies (D).

The injured or stimulated endothelium releases free tPA into the brain's circulation, which then preferentially activates fibrin-bound plasminogen, causing plasmin to be generated primarily within the fibrin clot.[42] Thrombin adjacent to microclots may also stimulate both tPA and PAI-1 release from the intact endothelium, whereas thrombin TM activated-protein C simultaneously inactivates PAI-1,[116] favoring fibrinolysis (Fig. 1). Fibrinolysis of the occluding thrombus after stroke leads to reperfusion of the damaged hypoxic vessels, but it may also cause diffuse petechial bleeding into the parenchyma from damaged microvasculature.

In vitro studies have demonstrated that production, release, and synthesis of tPA and its rapid inhibitor PAI-1 in systemic endothelial cells is regulated by various physiological and pathological stimuli. For example, coordinated induction of both IPA and PAI-1 has been reported with thrombin or basic fibroblast growth factor (bFGF), whereas histamine, activated protein $\mathrm{C}$, and phorbol ester induce tPA alone, and lipopolysaccharide (LPS), transforming growth factor- $\beta$, interleukin-1 (IL-1), or tumor 
necrosis factor-alpha (TNF-alpha) induce PAI-1 alone.[33,56,76,102-105] It has been shown that human systemic endothelial cells in vitro secrete more tPA when exposed to an arterial level of shear stress[26] and pulsatile stretch,[63] whereas PAI-1 secretion remains unaffected. It has been also demonstrated that tPA secretion and tPA mRNA are significantly upregulated after serial passages in culture, whereas the urokinase-type plasminogen activator gene that is normally not expressed in primary culture, becomes quite active at higher passage numbers. These studies suggest that the expression of each of the two antigens may be regulated independently by various chemical or mechanical stimuli and that under in vitro conditions their expression may be enhanced and/or modulated as a reaction to the tissue culture environment.

In vivo studies in nonhuman primates, in contrast to those performed in vitro studies, suggest that TNF-alpha plays a pivotal role in the release of both tPA and PAI-1 antigens during LPS (endotoxin) stimulation.[12] The release of both tPA and PAI-1 by LPS in vivo has also been reported in rats.[33] In vivo studies in rats when contrasted with in vivo studies in nonhuman primates indicated that neither TNF-alpha nor IL-1 is significantly involved in the induction of PAI-1 by LPS.[33] Among other differences, the expression of tPA in cerebral microvessels in nonhuman primates in vivo was found to be limited to some precapillary arterioles and postcapillary venules,[75] whereas in rats and guinea pigs tPA and PAI-1 antigens are expressed in cerebral capillaries in vivo.[70,133] It has also been shown recently that tPA and PAI-1 regulation in rat aorta in response to LPS differs from observations in mouse aorta and rat carotid artery.[91] Together these studies caution against extrapolation of results and conclusions obtained in one tissue or species subjected to specific types of stimuli to another, as well as from the in vitro setting to an in vivo situation.

\section{THEORIES OF STROKE}

There are several theories proposed to describe how ischemic stroke and cerebrovascular deficiency with critical reductions in CBF may develop. They are based on numerous clinical and experimental laboratory studies. It is noteworthy that these theories should not be regarded as mutually exclusive. On the contrary, they may explain the pathogenesis of impaired CBF, ischemic stroke, and cerebrovascular disease in a complementary fashion.

\section{Hemodynamic and Thromboembolic Theories}

Earlier studies have suggested that atherogenesis in extracranial arteries[127] may be a primary cause of hemodynamic[6] or thromboembolic[19] stroke. The hemodynamic theory argues that the frequency of transient ischemic attacks or strokes is directly correlated with the degree of atherosclerotic carotid stenosis. The thromboembolic theory argues that the extent of platelet accumulation on carotid plaques correlates with ipsilateral ischemic episodes. These theories have not been confirmed by subsequent studies.[17,20,50,57,95,108]

\section{Rheological Theory}

Rheological evidence has emphasized that $\mathrm{vWF}$ released from endothelial cells may have a crucial role to play in platelet aggregation in experimental conditions that may mimic the hemorheological situation of partially occluded arteries. $[64,85,86,93]$ It has been suggested that this pathway of platelet aggregation involving only one adhesive ligand (vWF) and two membrane adhesion receptors (glycoproteins Ib and IIb-IIIa) may play a significant role in thrombogenesis. Other factors that may have a role in high shear-induced aggregation are fibrinogen and fibronectin. 


\section{Hemostatic Theory}

Several clinical studies have demonstrated a link between ischemic stroke and immunohematological abnormalities consisting of 1) enhanced procoagulant mechanisms including marked platelet activation, activation of coagulation cascade, increased levels of fibrinogen, and thrombin; 2) reduced activity of the anticoagulant TM-protein C/protein S system including decreased levels of protein $\mathrm{C}$ and APC, deficiency of protein $\mathrm{S}$, increased levels of potential inhibitors of TM-dependent protein $\mathrm{C}$ activation (antiphospholipid antibody titer), and increased levels of inhibitors of protein S (C4bp, a regulatory protein in the classic complement pathway); and 3) depression of fibrinolysis, including reduced tPA activity, lower ratio of active tPA to PAI-1, and increased levels of fibrin D-dimer, an index of fibrin turnover.[2,3,5,15,18,22,23,51,62,79,80,84,100,101] These changes can be found from a few minutes up to 2 weeks after the onset of brain ischemia. It is not clear, however, whether these hemostatic abnormalities precede or follow the neurological event.

\section{Microcirculatory Theory}

Recent studies have provided strong experimental evidence to support the hypothesis that stroke may develop as a result of changes in the brain microcirculation.[53,54] It has been demonstrated that the stroke risk factors hypertension, diabetes, advanced age, and genetic predisposition may prepare rat brainstem tissue for the local Shwartzman reaction. The reaction is provoked by either intracisternal or intravenous injection of endotoxin. Endotoxin (LPS) is derived from the cell wall of Gram-negative bacteria and is a natural substance to which animals and humans are repeatedly exposed. Endotoxin has powerful effects on host humoral and cellular systems that mediate hemostasis and inflammation. Affected rats exhibit profound neurological impairment caused primarily by microthrombi and petechial hemorrhages in the brainstem. These studies have initially demonstrated that stroke risk factors may predispose the brain to ischemia by local effects on hemostatic systems in the cerebral microcirculation.

\section{Blood-Brain Barrier Theory}

The role of the $\mathrm{BBB}$ in ischemia has been recognized for some time in relation to the pathogenesis of cerebral edema and oxidative stress.[11,88] More recently, we initiated studies to examine whether changes in the expression and function of different hemostasis-related proteins at the BBB are associated with enhanced neurological impairments and neuropathological outcome and reduced CBF during the reperfusion phase after a focal ischemic insult. To test this hypothesis, we used experimental rat models of diabetes, nicotine administration, and hypertension as the major factors that increase the risk of cerebrovascular disease and ischemic stroke. The model of middle cerebral artery (MCA) occlusion followed by reperfusion, which is frequently studied to determine the pathophysiology, treatment, and mechanisms of focal cerebral ischemia, was also used. The studies have established the association between a focal ischemic insult and altered hemostatic BBB functions. Some critical results are detailed.

\section{STROKE RISK FACTORS, HEMOSTATIC ALTERATIONS, AND BBB MECHANISMS}

\section{Smoking}

Cigarette smoking has been accepted as a major factor that increases the risk of coronary disease, peripheral vascular disease, and stroke.[45] Although epidemiological studies in smokers may not translate directly into equivalent effects of nicotine (a major constituent of cigarette smoke), few recent clinical studies have indicated that the application of nicotine patches alone precipitates ischemic stroke 
in chronic smokers.[68,94] It has been suggested that smoking products and/or nicotine may predispose to cerebral thrombosis, possibly by causing an imbalance between brain vascular coagulation and fibrinolytic systems.[1,41,59] Altered coagulation and abnormal fibrinolysis have been shown in the blood of chronic smokers.[41,59,90]

Recently we demonstrated that chronic nicotine administration in rats, approximating the amount of nicotine intake via cigarette smoking in humans (equivalent to approximately 2-3 packages/day)[87] results in enhanced focal ischemic brain injury, poor neurological outcome, and impaired restoration of blood flow following reversible MCA occlusion when compared with that in control rats (Fig. 6A-C). Notably, the effect of nicotine on focal ischemic stroke was associated with complete depletion of the free pool of brain capillary tPA antigen in chronically treated rats, whereas PAI-1 antigen and PAI-1-tPA complexes remained unaffected by this treatment (Fig. 6D).[70] In addition, this nicotine treatment produced a marked decrease in brain capillary APC (that is, TM activity) accompanied by reduced levels of TM mRNA.[120] These results suggest that nicotine could significantly reduce local fibrinolytic and anticoagulant potential in brain microcirculation by completely depleting the free pool of microvascular tPA and drastically reducing TM activity.

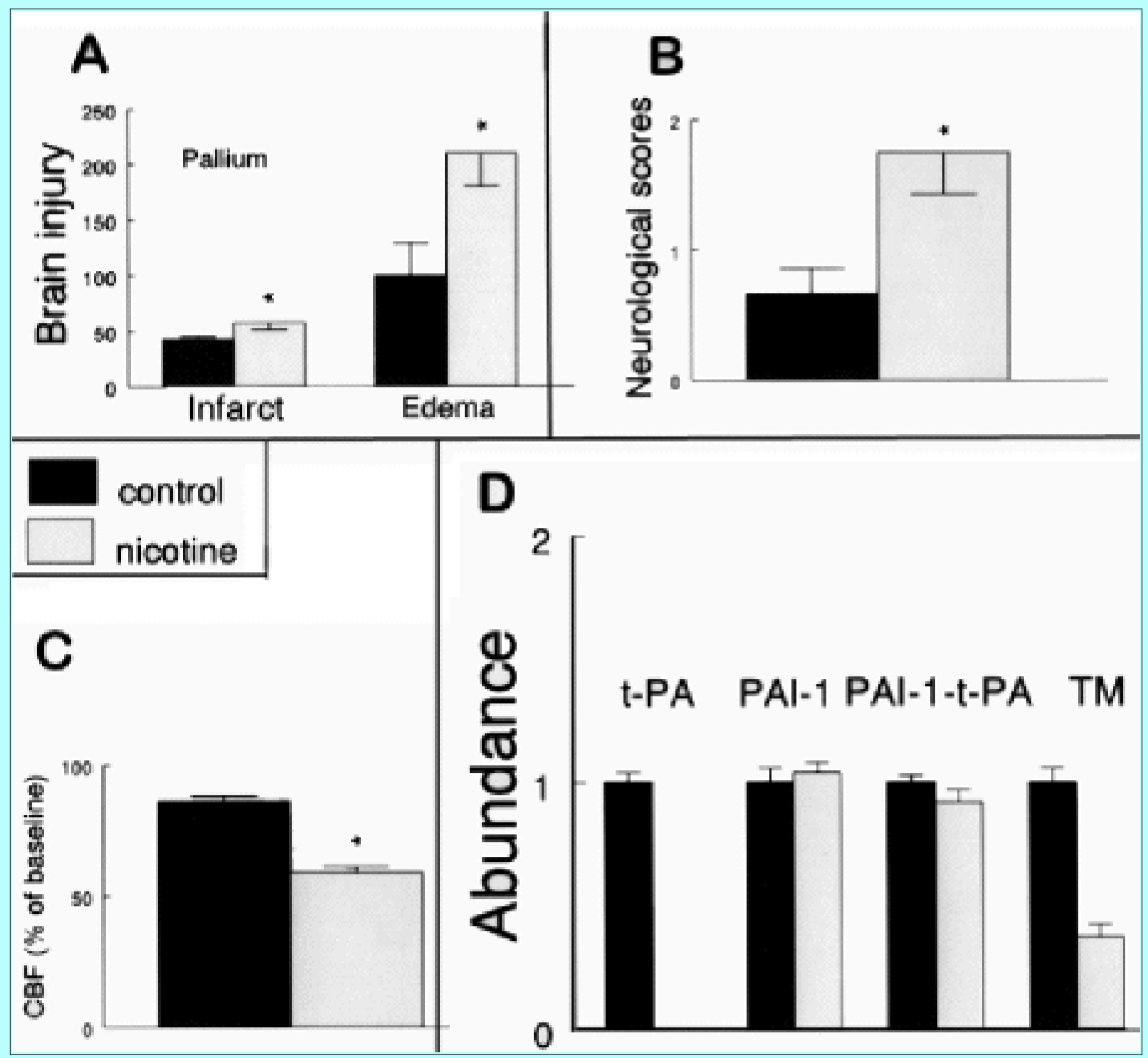

Fig. 6. Graphs showing the neuropathological outcome (A), motor neurological score (B), and reduction of $\mathrm{CBF}$ during reperfusion in the periphery of ischemic core $(\mathrm{C})$ after 1 hour 
of reversible MCA occlusion and 24 hours of reperfusion in control (black bars) and nicotine-treated rats $(4.5 \mathrm{mg}$ of nicotine-free base per day administered subcutaneously via osmotic minipumps for 14 days [gray bars]). A: The infarction volume of gray matter and the edema volume in the pallium of control animals were arbitrarily set at 100 . B: The scale for motor neurological score is within the range from 0 (no motor deficit) to 4 (cannot walk, depressed level of consciousness). C: Baseline values for $\mathrm{CBF}$ were determined before MCA occlusion and are arbitrarily set at 100 . Reductions of CBF were determined within 1 hour of reperfusion. There was no difference in the physiological variables (mean arterial blood pressure, temporalis muscle temperature, $\mathrm{PaO}_{2}, \mathrm{PaCO}_{2}, \mathrm{pH}$, and hematocrit) between control and nicotine-treated rats. D: The relative abundance of tPA and PAI-1 antigens, tPA-PAI-1 complexes, and TM activity in cerebral capillaries of control and nicotine-treated rats is illustrated. The results for tPA and PAI-1 were obtained by Western blot analysis of cerebromicrovascular proteins and for TM by determining the increase in APC from brain capillary cellular homogenates. The values in control animals were arbitrarily set at 1 . Modified from reference 119.

The only tPA that was found in the brain capillaries of nicotine-treated rats remained bound to PAI-1, and therefore is likely to be functionally inactive. The unchanged level of cerebromicrovascular PAI-1 antigen suggests that at this stage of chronic nicotine treatment (14 days) PAI-1 is most likely not involved in reducing the level of tPA antigen. The absence of increased amounts of PAI-1-tPA complexes in the microvasculature of nicotine-treated rats supports this hypothesis. The mechanism of tPA antigen depletion by nicotine in brain microvessels is presently not understood. The relative levels of tPA mRNA and $B$-actin mRNA in cerebral microvessels of nicotine-treated rats remain unchanged, suggesting that the effect of nicotine is mediated at the posttranscriptional level. There are many possible explanations for the dissociation between tPA mRNA and protein, including posttranslational modifications that result in altered tPA turnover, release, secretion, or antibody recognition. Variations in protein levels in the face of mRNA levels that do not change has been well documented.[61]

In vitro studies with systemic endothelial cells have demonstrated that morphological changes in endothelial cells (that is, cytoskeletal rearrangement, increase in monolayer permeability, and cellular shape change) may influence tPA gene expression independently of the PAI-1 gene expression.[26,63,77]. An ultrastructural analysis of brain microvasculature in the present nicotine model in rodents failed to demonstrate any morphological changes in brain endothelial cells in vivo, as was reported.[7] This is in contrast to giant cell formation, ruffled membranes and extensive cellular vacuolation, and mitochondrial swelling observed in systemic endothelial cells in response to nicotine.[14,115,131] The lack of ultrastructural alterations in brain endothelial cells in rodents may reflect a subthreshold exposure to nicotine, a different response of these cells to the toxin, and/or a difference between the species. The mechanism for TM downregulation at the BBB in this model is also unknown, and the role of cytokines, TNF-alpha and IL-1, is currently under investigation.

It is not certain whether the intermittent boluslike dosing of nicotine from cigarettes in habitual smokers could have different effects from those produced by continually released transdermal nicotine patches and/or by continuous chronic administration via subcutaneous mini pumps as described in recent study.[119] However, an association between the depletion of tPA antigen from the coronary vessels and the subsequent development of coronary artery disease in those patients has been reported.[74] It is also known that reduced APC levels in coronary circulation may predispose to myocardial infarction in a 
porcine model.[109] Thus, it is possible that depletion of the free tPA antigen pool and reduced APC within the brain microcirculation may compromise fibrinolytic capacity and anticoagulant function in smokers, which might predispose to larger and more disabling strokes. It has been also shown that acute exposure to nicotine increases the formation of reactive oxygen species in epithelial tissues.[123,124] Whether chronic nicotine administration results in free radical production in brain in vivo has not been investigated, but the possibility that the effect of nicotine on brain injury could be due to both vascular and neuronal effects should be considered.

\section{Diabetes}

It has been suggested that advanced glycosylated end-products (AGE) may play a central role in the pathogenesis of vascular changes that occur in patients with diabetes.[36] Advanced glycosylated end-products are proteins modified by nonenzymatic covalent glycosylation. In patients with diabetes AGEs accumulate progressively on other long-lived proteins in plasma and subendothelial tissues, including vascular basement membranes. Advanced glycosylated end-products proteins may modulate the expression of endothelial coagulation receptors in vitro by inducing TF expression and suppressing the activity of the TM pathway.[36] We recently demonstrated that streptozotocin-induced diabetes type 1 produces downregulation of tPA expression in rat brain capillaries without affecting PAI- $1 \mathrm{mRNA}$ expression. A marked downregulation of brain capillary TM activity was also found in this diabetic model. Depletion of brain capillary tPA and drastic reduction of the TM-protein $\mathrm{C}$ system in diabetic rats were associated with impaired restoration of $\mathrm{CBF}$ following reversible MCA occlusion, poor neurological outcome, and enhanced focal ischemic brain injury compared with both control rats and rats rendered acutely hyperglycemic to a comparable level by dextrose treatment (Fig. 7). 


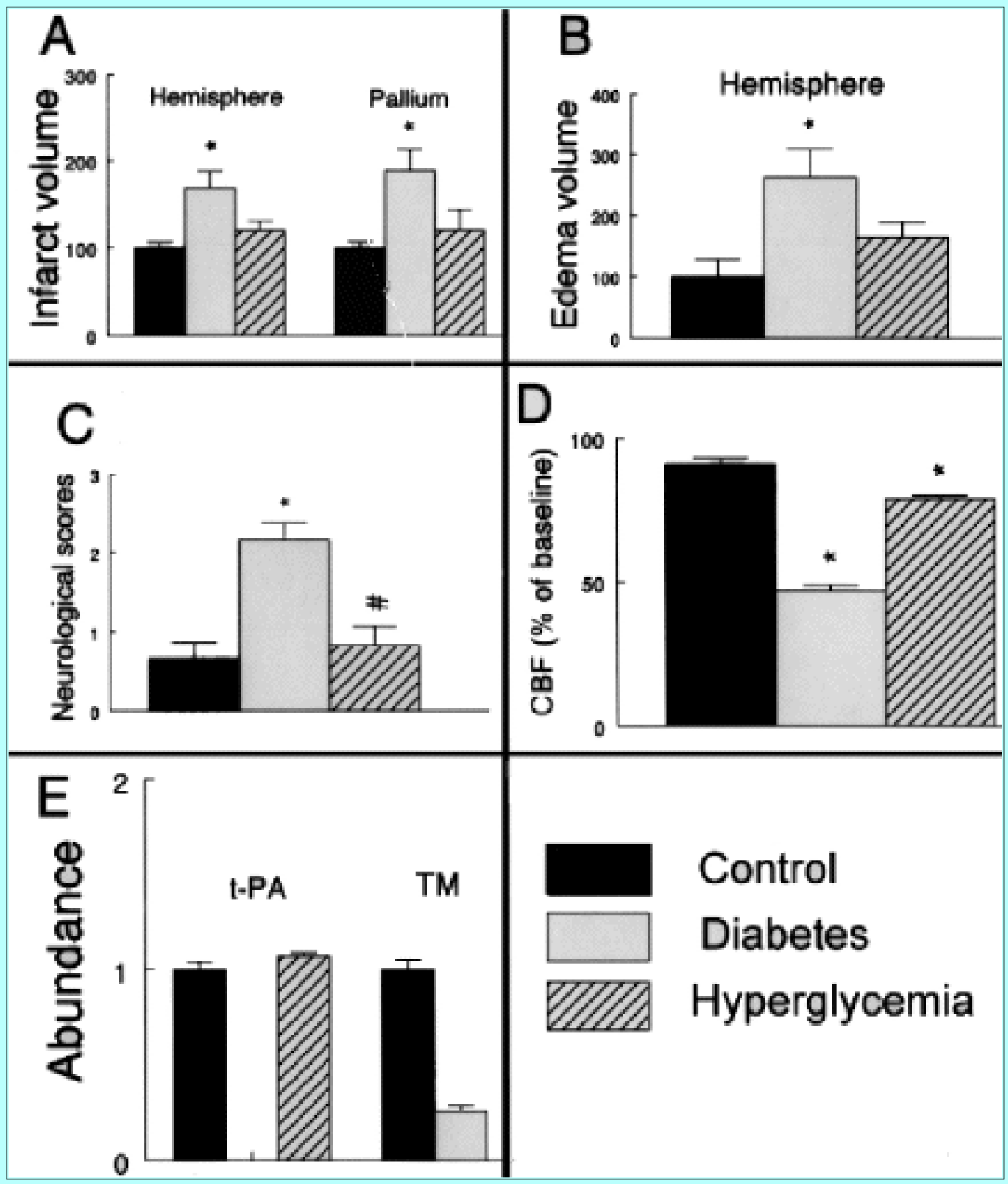

Fig. 7. Graphs depicting the neuropathological outcome (A,B), motor neurological score (C), and reductions in CBF during reperfusion in the periphery of ischemic core (D) after reversible 1-hour MCA occlusion and 24 hours of reperfusion in control, diabetic, and acutely hyperglycemic rats. Diabetes type I was induced by administration of streptozotocin for 7 days, and acute hyperglycemia was induced by administration of 50\% dextrose. All rats developed comparable hyperglycemia (approximately $15 \mathrm{mmol} / \mathrm{L}$ ). There was no difference in physiological variables (mean arterial blood pressure, temporalis muscle temperature, $\mathrm{PaO}_{2}, \mathrm{PaCO}_{2}, \mathrm{pH}$, and hematocrit) among control, diabetic, and hyperglycemic rats. The relative abundance of tPA antigen and TM activity in the cerebral capillaries of control and diabetic rats is illustrated in E. All other explanations are the same as those provided in Fig. 6. Modified from reference 70.

We demonstrated that complete tPA depletion and downregulation of TM activity in the brain capillaries 
of diabetic rats are likely caused by downregulation of tPA and TM synthesis at the transcriptional level.[70,120] The exact mechanism for this downregulation of tPA and TM mRNA in brain capillaries in diabetic subjects is presently unknown. An in vitro study indicated that elevated glucose does not affect tPA mRNA levels in bovine brain endothelial cells,[71] and it has been confirmed that hyperglycemia alone does not affect tPA levels in brain capillaries. Thus, other factors besides hyperglycemia may be implicated in altering brain hemostatic functions in the present diabetic model, including AGE and cytokines.[130]

Hyperglycemia has been shown in some models of ischemia to accentuate postischemic brain edema.[97,121] Detrimental effects precipitated by preischemic hyperglycemia and subsequent lactic acidosis on cerebral blood vessels and postischemic CBF have been documented in models of transient global brain ischemia.[47,92] However, studies on hyperglycemia and focal cerebral ischemia have been less consistent. It has been reported that hyperglycemia reduces the extent of cerebral infarction following irreversible photochemically induced end-arteriolar thrombosis in rats,[46] decreases acute ischemic neuronal changes after permanent MCA occlusion in cats,[129] does not affect the infarction volume after permanent MCA occlusion in rats,[89] increases the infarction size after permanent MCA occlusion in cats, [25] and increases the infarction size in collaterally perfused but does not affect end-arterial vascular territories after permanent MCA occlusion in rats.[96] In the reversible MCA model in cats, severe hyperglycemia significantly enhanced infarction size,[24] whereas moderate hyperglycemia did not cause a significant increase in the infarction in reversible MCA occlusion in fed versus fasted rats.[128] In a recent study, only modest increases in infarction size and edema volume and a modest reduction in CBF during reperfusion were observed in the hyperglycemia model.[70] (Fig. 7).

It is possible that diabetic animals had an impaired trend toward CBF restoration during the reperfusion period because of abnormal endogenous thrombolysis and depressed anticoagulation. It is also likely that the pathogenesis of brain injury in diabetes is multifactorial and could be mediated, in addition to lactic acidosis, by AGE proteins and cytokines, and impaired BBB fibrinolytic and anticoagulant functions.

\section{Hypertension}

Prolonged clot lysis time, lower tPA activity, increased platelet aggregation, elevated fibrinogen, increased PAI-1, and a link between cerebral venous thrombosis and hereditary protein C deficiency have been demonstrated in patients with mild essential hypertension.[73] These changes suggest impaired fibrinolysis and a procoagulant hemostatic blood profile. Experimental studies indicate that the spontaneous dissolution of a cerebral embolus is significantly lower in hypertensive compared with normotensive rats.[69] Recent studies also demonstrate that rats that are genetically prone to hypertension or spontaneously hypertensive rats with a mean arterial blood pressure of $175 \mathrm{~mm} \mathrm{Hg}$ develop brain microthrombi and petechial hemorrhages after a provocative dose of LPS.[53,54]

\section{CONCLUSIONS}

There is vast body of clinical evidence that emphasizes the importance of hemostasis in the pathophysiology of brain injury related to CBF deficiency and stroke.[37,38] The BBB appears to be an important mediator of brain regulation of hemostasis under physiological conditions and therefore plays an important role in brain protection by maintaining normal CBF. [70,118-120,132,133] Alterations in hemostatic functions at the BBB by stroke risk factors contribute to reductions in $\mathrm{CBF}$ and, following an ischemic insult, could predispose the brain to enhanced injury and larger infarctions. Thus, correcting hemostatic imbalance may result in improved $\mathrm{CBF}$ and could ameliorate drastic flow reductions at the 
time of an ischemic insult, ultimately resulting in brain protection. Delineation of the molecular mechanisms of BBB-mediated hemostasis will likely contribute to future stroke prevention efforts and brain protection strategies.

\section{Acknowledgment}

The author wishes to acknowledge the unpublished observations of L. Wang, M.D., on which he has drawn extensively throughout this article.

\section{References}

1. Allen RA, Kluft C, Brommer EJ: Effect of chronic smoking on fibrinolysis. Arteriosclerosis 5:443-450, 1985

2. Ameriso SF, Wong VL, Quismorio FP Jr, et al: Immunohematologic characteristics of infection-associated cerebral infarction. Stroke 22:1004-1009, 1991

3. Anzola GP, Magoni M, Ascari E, et al: Early prognostic factors in ischemic stroke. The role of protein C and protein S. Stroke 24:1496-1500, 1993

4. Astrup T: Assay and content of tissue thromboplastin in different organs. Thromb Diath Haemorrh 14:401-416, 1965

5. Autret A, Pourcelot L, Saudeau D, et al: Stroke risk in patients with carotid stenosis. Lancet 1:888-890, 1987

6. Barnett HJM: Pathogenesis of transient ischemic attacks, in Scheinberg P (ed): Cerebrovascular Diseases. Tenth Princeton Conference. New York: Raven Press, 1976, pp 1-21

7. Barron E, Lipovac MN, Zlokovic BV, et al: Morphologic alterations in neurohypophyseal endothelial cells of nicotine-treated guinea pigs. Soc Neurosci Abstr 18:1492, 1992 (Abstract)

8. Bauer KA, Kass BL, ten Cate H, et al: Factor IX is activated in vivo by the tissue factor mechanism. Blood 76:731-736, 1990

9. Bauer KA, Mannucci PM, Gringeri A, et al: Factor IXa-factor VIIIa-cell surface complex does not contribute to the basal activation of the coagulation mechanism in vivo. Blood 79:2039-2047, 1992

10. Bazan JF: Structural design and molecular evolution of a cytokine receptor superfamily. Proc Natl Acad Sci USA 87:6934-6938, 1990

11. Betz AL, Martz D, Randall J: Free radicals, ischemia, xanthine oxidase and the brain capillary, in Johansson BB, Owman C, Widner H (eds): Pathophysiology of the Blood-Brain Barrier. Long Term Consequences of Barrier Dysfunction for the Brain. Amsterdam: Elsevier, 1990, pp 333-341

12. Biemond BJ, Levi M, Ten Cate $\mathrm{H}$, et al: Plasminogen activator and plasminogen activator inhibitor 1 release during experimental endotoxaemia in chimpanzees: effect of interventions in the cytokine and coagulation cascades. Clin Sci 88:587-594, 1995

13. Boffa MC, Jackman RW, Peyri N, et al: Thrombomodulin in the central nervous system. Nouv Rev Fr Hematol 33:423-429, 1991 
14. Booyse FM, Osikowicz G, Quarfoot AJ: Effects of chronic oral consumption of nicotine on the rabbit aortic endothelium. Am J Pathol 102:229-238, 1981

15. Bots ML, Breslau PJ, Briet E, et al: Cardiovascular determinants of carotid artery disease. The Roterdam Elderly Study. Hypertension 19:717-720, 1992

16. Broze GJ Jr, Miletich JP: Biochemistry and physiology of protein C, protein S, and thrombomodulin, in Colman RW, Hirsh J, Marder VJ, et al (eds): Hemostasis and Thrombosis. Basic Principles and Clinical Practice, ed 3. Philadelphia: JB Lippincott, 1994, pp 241-259

17. Busuttil RW, Baker JD, Davidson RK, et al: Carotid artery stenosis--hemodynamic significance and clinical course. JAMA 245:1438-1441, 1981

18. Camerlingo M, Finazzi G, Casto L, et al: Inherited protein C deficiency and nonhemorrhagic arterial stroke in young adults. Neurology 41:1371-1373, 1991

19. Castaigne P, Lhermitte F, Gautier JC, et al: Internal carotid artery occlusion. A study of 61 instances in 50 patients with post-mortem data. Brain 93:231-258, 1970

20. Chambers BR, Norris JW: The case against surgery for asymptomatic carotid stenosis. Stroke 15:964-967, 1984

21. Collen D: On the regulation and control of fibrinolysis. Thromb Haemost 43:77-89, 1980

22. Cortellaro M, Boshetti C, Cofrancesco E, et al: The PLAT Study: a multidisciplinary study of hemostatic function and conventional risk factors in vascular disease patients. Atherosclerosis 90:109-118, 1991

23. D'Angelo A, Landi G, Vigano' D'Angelo S, et al: Protein C in acute stroke. Stroke 19:579-583, 1988 24. de Courten-Myers GM, Kleinholz M, Wagner KR, et al: Fatal strokes in hyperglycemic cats. Stroke 20:1707-1715, 1989

25. de Courten-Myers GM, Myers RE, Schoolfield L: Hyperglycemia enlarges infarct size in cerebrovascular occlusion in cats. Stroke 19:623-630, 1988

26. Diamond SL, Eskin SG, McIntire LV: Fluid flow stimulates tissue plasminogen activator secretion by cultured human endothelial cells. Science 243:1483-1485, 1989

27. Dittman WA, Kumada T, Sadler JE, et al: The structure and function of mouse thrombomodulin. Phorbol myristate acetate stimulates degradation and synthesis of thrombomodulin without affecting mRNA levels in hemangioma cells. J Biol Chem 263:15815-15822, 1988

28. Dittman WA, Majerus PW: Structure and function of thrombomodulin: a natural anticoagulant. Blood 75:329-336, 1990

29. Drake TA, Morrissey JH, Edgington TS: Selective cellular expression of tissue factor in human tissues. Implications for disorders of hemostasis and thrombosis. Am J Pathol 134:1087-1097, 1989

30. Durieu-Trautmann O, Bourdoulous S, Roux F, et al: Immortalized rat brain microvessel endothelial cells: II-pharmacological characterization. Adv Exp Med Biol 331:205-210, 1993 
31. Eddleston M, de la Torre JC, Oldstone MB, et al: Astrocytes are the primary source of tissue factor in the murine central nervous system. A role for astrocytes in cerebral hemostasis. J Clin Invest 92:349-358, 1993

32. Edgington TS, Mackman N, Fan ST, et al: Cellular immune and cytokine pathways resulting in tissue factor expression and relevance to septic shock. Nouv Rev Fr Hematol 34 (Suppl):S15-S27, 1992

33. Emeis JJ, Kooistra T: Interleukin 1 and lipopolysaccharide induce an inhibitor of tissue-type plasminogen activator in vivo and in cultured endothelial cells. J Exp Med 163:1260-1266, 1986

34. Esmon CT: The regulation of natural anticoagulant pathways. Science 235:1348-1352, 1987

35. Esmon CT: The roles of protein $\mathrm{C}$ and thrombomodulin in the regulation of blood coagulation. $\mathbf{J}$ Biol Chem 264:4743-4746, 1989

36. Esposito C, Gerlach H, Brett J, et al: Endothelial receptor-mediated binding of glucose-modified albumin is associated with increased monolayer permeability and modulation of cell surface coagulant properties. J Exp Med 170:1387-1407, 1989

37. Fisher M: Immunohematologic mechanisms in stroke, in Caplan LR (ed): Brain Ischemia: Basic Concepts and Clinical Relevance. New York: Springer-Verlag, 1995, p 7

38. Fisher M, Francis R: Altered coagulation in cerebral ischemia. Platelet, thrombin, and plasmin activity. Arch Neurol 47:1075-1079, 1990

39. Fisher M, Lipovac M, Martin A, et al: Hemostasis regulation in guinea pig brain. Soc Neurosci Abs 18:408, 1992 (Abstract)

40. Fleck RA, Rao LV, Rapaport SI, et al: Localization of human tissure factor antigen by immunostaining with monopecific, polyclonal anti-human tissue factor antibody. Thromb Res $\mathbf{5 7 : 7 6 5 - 7 8 1 , 1 9 9 0}$

41. Folts JD: Cigarette smoking and thrombus formation. Am Heart J 116:1657-1658, 1988

42. Francis RB Jr: Clinical disorders of fibrinolysis: a critical review. Blut 59:1-14, 1989

43. Furie B, Furie BC: Molecular and cellular biology of blood coagulation. N Engl J Med 326:800-806, 1992

44. Gibbs CS, Coutre SE, Tsiang M, et al: Conversion of thrombin into an anticoagulant by protein engineering. Nature 378:413-416, 1995

45. Gill JS, Shipley MJ, Tsementzis SA, et al: Cigarette smoking. A risk factor for hemorrhagic and nonhemorrhagic stroke. Arch Intern Med 149:2053-2057, 1989

46. Ginsberg MD, Prado R, Dietrich WD, et al: Hyperglycemia reduces the extent of cerebral infarction in rats. Stroke 18:570-574, 1987

47. Ginsberg MD, Welsh FA, Budd WW: Deleterious effect of glucose pretreatment on recovery from diffuse cerebral ischemia in the cat. I. Local cerebral blood flow and glucose utilization. Stroke 11:347-355, 1980 
48. Gomi K, Zushi M, Honda G, et al: Antithrombotic effect of recombinant human thrombomodulin on thrombin-induced thromboembolism in mice. Blood 75:1396-1399, 1990

49. Griffin JH: Blood coagulation. The thrombin paradox. Nature 378:337-338, 1995

50. Grotta JC, Bigelow RH, Hu H, et al: The significance of carotid stenosis or ulceration. Neurology 34:437-442, 1984

51. Gruber A, Griffin JH: Direct detection of activated protein C in blood from human subjects. Blood 79:2340-2348, 1992

52. Gruber A, Harker LA, Hanson SR, et al: Antithrombotic effects of combining activated protein C and urokinase in nonhuman primates. Circulation 84:2454-2462, 1991

53. Hallenbeck JM, Dutka AJ, Kochanek PM, et al: Stroke risk factors prepare rat brainstem tissues for modified local Shwartzman reaction. Stroke 19:863-869, 1988

54. Hallenbeck JM, Dutka AJ, Vogel SN, et al: Lipopolysaccharide-induced production of tumor necrosis factor activity in rats with and without risk factors for stroke. Brain Res 541:115-120, 1991

55. Hanson SR, Griffin JH, Harker LA, et al: Antithrombotic effects of thrombin-induced activation of endogenous protein C in primates. J Clin Invest 92:2003-2012, 1993

56. Hanss M, Collen D: Secretion of tissue-type plasminogen activator and plasminogen activator inhibitor by cultured human endothelial cells: modulation by thrombin, endotoxin, and histamine. J Lab Clin Med 109:97-104, 1987

57. Harrison MJ, Marshall J: Prognostic significance of severity of carotid atheroma in early manifestations of cerebrovascular disease. Stroke 13:567-569, 1982

58. Hartzell S, Ryder K, Lanahan A, et al: A growth factor-responsive gene of murine BALB/c 3 T3 cells encodes a protein homologous to human tissue factor. Mol Cell Biol 9:2567-2573, 1989

59. Hashimoto Y, Kobayashi A, Yamazaki N, et al: Relationship between smoking and fibrinolytic system with special reference to tPA and PA inhibitor. Thromb Res 51:303-311, 1988

60. Heeb MJ, Gruber A, Griffin JH: Identification of divalent metal ion-dependant inhibition of activated protein $\mathrm{C}$ by alpha 2-macroglobulin and alpha 2-antiplasmin in blood and comparisons to inhibition of factor Xa, thrombin, and plasmin. J Biol Chem 266:17606-17612, 1991

61. Hengst L, Reed SI: Translational control of p27Kip1 accumulation during the cell cycle. Science 271:1861-1864, 1996

62. Heye N, Paetzold C, Cervos-Navarro J: The role of microthrombi and microcirculatory factors in localization and evolution of focal cerebral ischemia. Neurosurg Rev 14:7-16, 1991

63. Iba T, Shin T, Sonoda T, et al: Stimulation of endothelial secretion of tissue-type plasminogen activator by repetitive stretch. J Surg Res 50:457-460, 1991

64. Ikeda Y, Handa M, Kawano K, et al: The role of von Willebrand factor and fibrinogen in platelet aggregation under varying shear stress. J Clin Invest 87:1234-1240, 1991 
65. Isaka T, Yoshimine T, Maruno M, et al: Altered expression of antithrombotic molecules in human glioma vessels. Acta Neuropathol 87:81-85, 1994

66. Ishii H, Salem HH, Bell CE, et al: Thrombomodulin, an anticoagulant protein, is absent from the human brain. Blood 67:362-365, 1986

67. Jackman RW, Beeler DL, VanDeWater L, et al: Characterization of a thrombomodulin cDNA reveals structural similarity to the low density lipoprotein receptor. Proc Natl Acad Sci USA 83:8834-8838, 1986

68. Jackson M: Cerebral arterial narrowing with nicotine patch. Lancet 342:236-237, 1993 (Letter)

69. Kimata H, Nakajima K, Suzuki H, et al: Fibrinolytic effect of tissue plasminogen activator on cerebral embolism in stroke-prone spontaneously hypertensive rats. Chem Pharm Bull 39:3327-3330, 1991

70. Kittaka M, Wang L, Sun N, et al: Brain capillary tissue plasminogen activator in a diabetes stroke model. Stroke 27:712-719, 1996

71. Kollros PR, Konkle BA, Ambarian AP, et al: Plasminogen activator inhibitor-1 expression by brain microvessel endothelial cells is inhibited by elevated glucose. J Neurochem 63:903-909, 1994

72. Kumada T, Dittman WA, Majerus PW: A role for thrombomodulin in the pathogenesis of thrombin-induced thromboembolism in mice. Blood 71:728-733, 1987

73. Landin K, Tengborn L, Smith U: Elevated fibrinogen and plasminogen activator inhibitor (PAI-1) in hypertension are related to metabolic risk factors for cardiovascular disease. J Intern Med 227:273-278, 1990

74. Labarrere CA, Pitts D, Nelson DR, et al: Vascular tissue plasminogen activator and the development of coronary artery disease in heart-transplant recipients. N Engl J Med 333:1111-1116, 1995

75. Levin EG, del Zoppo GJ: Localization of tissue plasminogen activator in the endothelium of a limited number of vessels. Am J Pathol 144:855-861, 1994

76. Levin EG, Santell L: Stimulation and desensitization of tissue plasminogen activator release from human endothelial cells. J Biol Chem 263:9360-9365, 1988

77. Levin EG, Santell L, Saljooque F: Hyperosmotic stress stimulates tissue plasminogen activator expression by a PCK-independent pathway. Am J Physiol 265:C387-C396, 1993

78. Loskutoff DJ, Sawdey M, Keeton M, et al: Regulation of PAI-1 gene expression in vivo. Thromb Haemost 70:135-137, 1993

79. Macko RF, Ameriso SF, Gruber A, et al: Impairments of the protein C system and fibrinolysis in infection-associated stroke. Stroke 27:2005-2011, 1996

80. Martinez HR, Rangel-Guerra RA, Marfil LJ, et al: Ischemic stroke due to deficiency of coagulation inhibitors. Report of 10 young adults. Stroke 24:19-25, 1993

81. Maruno M, Yoshimine T, Isaka T, et al: Expression of thrombomodulin in astrocytomas of various malignancy and in gliotic and normal brains. J Neurooncol 19:155-160, 1994 
82. McComb RD, Miller KA, Carson SD: Tissue factor antigen in senile plaques of Alzheimer's disease. Am J Pathol 139:491-494, 1991

83. McEver RP: Leukocyte interactions mediated by selectins. Thromb Haemost 66:80-87, 1991

84. Meissner I, Wiebers DO, Whisnant JP, et al: The natural history of asymptomatic carotid artery occlusive lesions. JAMA 258:2704-2707, 1987

85. Moake JL, Turner NA, Stathopoulos NA, et al: Involvement of large plasma von Willebrand factor (vWF) multimers and unusually large vWF forms derived from endothelial cells in shear stress-induced platelet aggregation. J Clin Invest 78:1456-1461, 1986

86. Moake JL, Turner NA, Stathopoulos NA, et al: Shear-induced platelet aggregation can be mediated by vWF released from platelets, as well as by exogenous large or unusually large vWF multimers, requires adenosine diphosphate, and is resistant to aspirin. Blood 71:1366-1374, 1988

87. Murrin LC, Ferrer JR, Zeng WY, et al: Nicotine administration to rats: methodological considerations. Life Sci 40:1699-1708, 1987

88. Nagashima G, Nowak TS Jr, Joo F, et al: The role of the blood-brain barrier in ischemic brain lesions, in Johansson BB, Owman C, Widner H (eds): Pathophysiology of the Blood-Brain Barrier. Long Term Consequences of Barrier Dysfunction for the Brain. Amsterdam: Elsevier, 1990, pp $311-333$

89. Nedergaard M, Diemer NH: Focal ischemia of the rat brain with special reference to the influence of plasma glucose concentration. Acta Neuropathol 73:131-137, 1987

90. Ozdemir O, Karaaslan Y, Ozcebe O, et al: The acute effect of smoking on platelet and endothelial release reaction is suppressed in chronic smokers. Thromb Res 65:263-274, 1992

91. Padro T, Quax PH, van den Hoogen C, et al: Tissue plasminogen activator and its inhibitor in rat aorta. Effect of endotoxin. Arterioscler Thromb 14:1459-1465, 1994

92. Paljarvi L, Rehncrona S, Soderfeldt B, et al: Brain lactic acidosis and ischemic cell damage: quantitative ultrastructural changes in capillaries of rat cerebral cortex. Acta Neuropathol 60:232-240, 1983

93. Peterson DM, Stathopoulos NA, Giorgio TD, et al: Shear-induced platelet aggregation requires von Willebrand factor and platelet membrane glycoproteins Ib and IIb-IIIa. Blood 69:625-628, 1987

94. Pierce JR Jr: Stroke following application of a nicotine patch. Ann Pharmacother 28:402, 1994 (Letter)

95. Powers WJ, Siegel BA, Davis HH II, et al: Indium-111 platelet scintigraphy in cerebrovascular disease. Neurology 32:938-943, 1982

96. Prado R, Ginsberg MD, Dietrich WD, et al: Hyperglycemia increases infarct size in collaterally perfused but not end-arterial vascular territories. J Cereb Blood Flow Metab 8: 186-192, 1988

97. Pulsinelli WA, Waldman S, Rawlinson D, et al: Moderate hyperglycemia augments ischemic brain damage: a neuropathologic study in the rat. Neurology 32:1239-1246, 1982 
98. Qian Z, Gilbert ME, Colicos MA, et al: Tissue-plasminogen activator is induced as an immediate-early gene during seizure, kindling and long-term potentiation. Nature 361:453-457, 1993

99. Renaud S, de Lorgeril M: Wine, alcohol, platelets, and the French paradox for coronary heart disease. Lancet 339:1523-1526, 1992

100. Ridker PM, Hennekens CH, Strampfer MJ, et al: Prospective study of endogenous tissue plasmonigen activator and risk of stroke. Lancet 343:940-943, 1994

101. Sacco RL, Owen J, Mohr JP, et al: Free protein S deficiency: a possible association with cerebrovascular occlusion. Stroke 20:1657-1661, 1989

102. Sakata Y, Curriden S, Lawrence D, et al: Activated protein C stimulates the fibrinolytic activity of cultured endothelial cells and decreases antiactivator activity. Proc Natl Acad Sci USA 82:1121-1125, 1985

103. Saksela O, Moscatelli D, Rifkin DB: The opposing effect of basic fibroblast growth factor and transforming growth factor beta on the regulation of plasminogen activator activity in capillary endothelial cells. J Cell Biol 105:957-963, 1987

104. Sawdey M, Podor TJ, Loskutoff DJ: Regulation of type 1 plasminogen activator inhibitor gene expression in cultured bovine aortic endothelial cells. Induction by transforming growth factor- $\beta$, lipopolysaccharide, and tumor necrosis factor-alpha. J Biol Chem 264:10396-10401, 1989

105. Schleef RR, Bevilacqua MP, Sawdey M, et al: Cytokine activation of vascular endothelium. Effects on tissue-type plasminogen activator and type 1 plasminogen activator inhibitor. J Biol Chem 263:5797-5803, 1988

106. Seeds NW, Williams BL, Bickford PC: Tissue plasminogen activator induction in Purkinje neurons after cerebellar motor learning. Science 270:1992-1994, 1995

107. Shatos MA, Orfeo T, Doherty JM, et al: a-Thrombin stimulates urokinase production and DNA synthesis in cultured human cerebral microvascular endothelial cells. Arterioscler Thromb Vasc Biol 15:903-911, 1995

108. Skinhoj E, Hoedt-Rasmussen K, Paulson OB, et al: Regional cerebral blood flow and its autoregulation in patients with transient focal cerebral ischemic attacks. Neurology 20:485-493, 1970

109. Snow TR, Deal MT, Dickey DT, et al: Protein C activation following coronary artery occlusion in the in situ porcine heart. Circulation 84:293-299, 1991

110. Stearns-Kurosawa DJ, Kurosawa S, Mollica JS, et al: The endothelial cell protein C receptor augments protein $\mathrm{C}$ activation by the thrombin-thrombomodulin complex. Proc Natl Acad Sci USA 93:10212-10216, 1996

111. Svensson PJ, Dahlback B: Resistance to activated protein C as a basis for venous thrombosis. $\mathbf{N}$ Engl J Med 330:517-522, 1994

112. Taylor FB Jr, Chang A, Esmon CT, et al: Protein C prevents the coagulopathic and lethal effects of Escherichia coli injection in the baboon. J Clin Invest 79:918-925, 1987 
113. Tran ND, Wong VL, Schreiber SS, et al: Regulation of brain capillary endothelial thrombomodulin mRNA expression. Stroke 27:2304-2310, 1996

114. Tsirka SE, Gualandris A, Amaral DG, et al: Excitotoxin-induced neuronal degeneration and seizure are mediated by tissue plasminogen activator. Nature 377:340-344, 1995

115. Tulloss JH, Booyse FM: Effect of various agents and physical damage on giant cell formation in bovine aortic endothelial cell cultures. Microvasc Res 16:51-58, 1978

116. Van Hinsberg VW, Bertina RM, Van Wijngaarden A, at el: Activated protein C decreases plasminogen activator-inhibitor activity in endothelial cell-conditioned medium. Blood 65:444-451, 1985

117. Vorbrodt AW: Ultracytochemical characterization of anionic sites in the wall of brain capillaries. J Neurocytol 18:359-368, 1989

118. Wang L, Kittaka M, Schreiber SS, et al: Regulation of thrombomodulin expression in bovine brain capillaries. Stroke 27:187, 1996 (Abstract)

119. Wang L, Kittaka M, Sun N, et al: Chronic nicotine treatment enhances focal ischemic brain injury and depletes free pool of brain microvascular tissue plasminogen activator in rats. J Cereb Blood Flow Metab 17:136-146, 1997

120. Wang L, Tran ND, Schreiber SS, et al: Thrombomodulin expression in rat brain capillaries: down-regulation in diabetic and chronic nicotine intoxication models. Stroke 28:259, 1997 (Abstract)

121. Warner DS, Smith ML, Siesjö BK: Ischemia in normo- and hyperglycemic rats: effects on brain water and electrolytes. Stroke 18:464-471, 1987

122. Wen D, Dittman WA, Ye RD, et al: Human thrombomodulin: complete cDNA sequence and chromosome localization of the gene. Biochemistry 26:4350-4357, 1987

123. Wetscher GJ, Bagchi D, Perdikis G, et al: In vitro free radical production in rat esophageal mucosa induced by nicotine. Digest Dis Sci 40:853-858, 1995

124. Wetscher GJ, Bagchi M, Bagchi D, et al: Free radical production in nicotine treated pancreatic tissue. Free Radical Biol Med 18:877-882, 1995

125. Williams WJ: The activity of human placenta microsomes and brain particles in blood coagulation. J Biol Chem 241:1840-1846, 1966

126. Wong VL, Hofman FM, Ishii H, et al: Regional distribution of thrombomodulin in the human brain. Brain Res 556:1-5, 1991

127. Yatsu FM: Atherogenesis and stroke, in Barnett HJM, Mohr JP, Stein BM, et al (eds): Stroke. Pathophysiology, Diagnosis, and Management. New York: Churchill Livingstone, 1986, Vol 1, pp $45-56$

128. Yip PK, He YY, Hsu CY, et al: Effect of plasma glucose on infarct size in focal cerebral ischemia-reperfusion. Neurology 41:899-905, 1991

129. Zasslow MA, Pearl RG, Shuer LM, et al: Hyperglycemia decreases acute neuronal ischemic 
changes after middle cerebral artery occlusion in cats. Stroke 20:519-523, 1989

130. Zimmerman GA, Meistrell M III, Bloom O, et al: Neurotoxicity of advanced glycation endproducts during focal stroke and neuroprotective effects of aminoguanidine. Proc Natl Acad Sci USA 92:3744-3748, 1995

131. Zimmerman M, McGeachie J: The effect of nicotine on aortic endothelium. A quantitative ultrastructural study. Atherosclerosis 63:33-41, 1987

132. Zlokovic BV, Wang L, Schreiber SS, et al: Haemostatic functions of the blood-brain barrier: possible implications in the pathogenesis of stroke, in Greenwood J, Begley DJ, Segal MB (eds): New Concepts of a Blood-Brain Barrier. New York: Plenum, 1995, pp 141-145

133. Zlokovic BV, Wang L, Sun N, et al: Expression of tissue plasminogen activator in cerebral capillaries: possible fibrinolytic function of the blood-brain barrier. Neurosurgery 37:955-961, 1995

Manuscript received May 20, 1997.

Accepted in final form May 23, 1997.

This work was supported by funds from the Cigarette and Tobacco Surtax Fund of the State of California through the Tobacco-Related Disease Research Program of the University of California, Grant No. 2RT0071, the Hoover Foundation, and National Institutes of Health Grant No. PO1NS31945.

Address reprint requests to: Berislav V. Zlokovic, M.D., Ph.D., 2025 Zonal Avenue, RMR 506, Los Angeles, California 90033. email: zlokovic@ hsc.usc.edu. 